21
Extent, Kinematics and Tectonic Origin of the Precambrian Aswa Shear Zone in

\section{Eastern Africa}

(1)

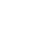

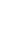

Andrew Katumwehe, Mohamed G. Abdelsalam, Estella Atekwana, Daniel A. Laó-Dávila

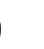

(1)

Boone Pickens School of Geology

Oklahoma State University

105 Noble Research Center

Stillwater, OK, 74078. USA

Corresponding Author: Mohamed G. Abdelsalam

mohamed.abdel_salam@okstate.edu

7

8

9

0

22

Gondwana Research Submitted June, 2014

3

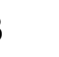




\section{Abstract}

The Aswa Shear zone (ASZ) is a fundamental Precambrian lithospheric structure that has

26 been shaped by many tectonic events in eastern Africa. It separates the Saharan Metacraton in

27 the northeast from the Northern Uganda terrane (which represents part of the Northeastern

28 Congo block of the Congo craton) to the southwest. Nonetheless, its tectonic evolution is not

29 fully understood. We used high-resolution airborne magnetic and radiometric data over Uganda

30 integrated with Shuttle Radar Topography Mission (SRTM) Digital Elevation Model (DEM) in

31 South Sudan to assess the extent, kinematics and contribute to the understanding of the tectonic

32 origin of the ASZ. (1) Our results showed that the ASZ extends in a NW-SE for $\sim 550 \mathrm{~km}$ in

33 Uganda and South Sudan. (2) The airborne magnetic and radiometric data revealed a much wider

$34(\sim 50 \mathrm{~km})$ deformation belt than the $5-10 \mathrm{~km}$ of the exposed surface expression of the ASZ. The

35 deformation belt is defined by three NW-trending sinistral strike-slip shear zones bounding

36 structural domains with magnetic fabric showing splays of secondary shear zones and shear-

37 related folds. These folds are tighter close to the discrete shear zones with their axial traces

38 becoming sub-parallel to the shear zones. A similar fold pattern is observed in South Sudan from

39 the SRTM DEM. We interpreted these folds as due to ENE-WSW contraction associated with

40 the sinistral strike-slip movement. (3) To the northeast, the magnetic patterns and radiometric

41 signature suggest the presence of a series of W-verging nappes indicative of strong E-W to NE-

42 SW contraction deformation. (4) We relate the evolution of the ASZ to E-W to NE-SW

43 Neoproterozoic oblique collision between East and West Gondwana. The deformation related to

44 this collision was partitioned into E-W to NE-SW contraction resulting in W-verging thrusts in

45 the east and a sinistral strike-slip movement along the NW-trending ASZ with the strain

46 localized at the boundary between the Saharan Metacraton and the Northern Uganda terrane. 
47 Keywords: Aswa Shear Zone, Saharan Metacraton, Congo craton, East African Orogen, 48 Gondwana.

\section{$50 \quad$ 1. Introduction}

The Aswa Shear Zone (ASZ) is a fundamental NW-trending Precambrian structure in the

52 central part of Gondwana (Figure 1A). Traces of the shear zone have been mapped in eastern and 53 central Africa extending in a NW-SE direction from South Sudan in the northwest through

54 Uganda, Kenya and Tanzania to the southeast and possibly into Madagascar as the Ranotsara 55 shear zone (Figure 1A; Collins et al., 2003). It has been proposed that the ASZ extends further 56 southeast into south India as the Achankovil shear zone in a Greater Gondwana reconstruction 57 (Figure 1A; Santosh and Collins, 2003; Pradeepkumar and Krishnanath, 2000). Until recently, 58 only a few generalized studies have attempted to explain the Precambrian evolution of the ASZ 59 and most of these attempts correlated the shear zone to other Neoproterozoic NW-trending 60 strike-slip shear zones in the Arabian-Nubian Shield, the most prominent of which is the Najd

61 fault system which is exposed in northwestern Saudi Arabian and the Eastern Desert of Egypt 62 (Figure 1A; Berhe, 1990; Stern 1994). Both Berhe (1990) and Stern (1994) suggested that the 63 development of the ASZ can be linked to the collision between East and West Gondwana similar 64 to other NW-trending strike-slip shear zones in the Arabian-Nubian Shield.

65 Besides its importance in understanding the Precambrian evolution of East and West 66 Gondwana and their lithospheric structure, the ASZ is also important for understanding the 67 development of Mesozoic and Cenozoic rifts, seismicity distribution, and controls on the Nile 68 drainage system in eastern Africa. Recent studies in Uganda (Westerhof et al., 2014; 69 Ruotoistenmaki, 2014; Nyakecho and Hagemann, 2014) have highlighted the importance of the 
70 ASZ, especially as a major Precambrian structure. However, the lack of geological investigations

71 in the better exposed part of the ASZ in South Sudan hinders full understanding of the 72 geodynamic evolution of this structure.

73 In this work, we attempt to define the extent and explain the kinematics of the ASZ in

74 Uganda and South Sudan benefiting from the availability of Shuttle Radar Topography Mission

75 (SRTM) Digital Elevation Model (DEM) and the newly acquired high resolution airborne 76 geophysical data from Uganda. Additionally, we propose an origin for the ASZ within the 77 context of East and West Gondwana tectonics.

\subsection{The ASZ and Gondwana tectonics}

Abdelsalam et al. $(2002,2011)$ suggested that the ASZ might represent the boundary

81 between the Saharan Metacraton in the northeast and the Congo craton to the southwest (Figure

82 1A). The extent of the Congo craton in northeastern Congo and northwestern Uganda is referred

83 to as the Northeastern Congo block (Figure 1B; Tack et al., 2010; Fernandez et al. 2012). This

84 region has been further divided by Westerhof et al. (2014) into the Northern Uganda terrane, the

85 West Nile terrane, the Lake Victoria terrane, and the West Tanzania terrane (Figure 1B). This

86 new sub-division makes the ASZ in Uganda the boundary between the Saharan Metacraton in the

87 northeast and the Northern Uganda terrane to the southwest (Figure 1B). However, Westerhof et

88 al. (2014) considered the portion of the Saharan Metacraton immediately northeast of the ASZ to

89 represent the continuation of the Northern Uganda terrane. Based on geophysical evidence that

90 will be discussed below, we consider the region to the northeast of the ASZ in Uganda and South

91 Sudan as part of the Saharan Metacraton. 
The ASZ has been correlated to other NW-trending shear zones (including the Najd fault

93 system) in the Mozambique belt in the south and the Arabian-Nubian Shield to the north that are

94 collectively named the East African Orogeny (Figure 1; Stern, 1994). Burke and Sengor (1986)

95 and Berhe (1990) postulated that the NW-trending shear zones together with minor NE-trending

96 strike-slip shear zones represent conjugate sets of sinistral and dextral strike-slip fault systems,

97 respectively. Further, Burke and Sengor (1986) and Berhe (1990) proposed that the shear zones

98 were formed as a result of Neoproterozoic oblique collision between East and West Gondwana

99 as escape roots due to northward expulsion of the Arabian-Nubian Shield from the Mozambique

100 belt. However, Abdelsalam and Stern (1991) pointed out that the locations, trends and kinematics

101 of these fault systems do not reconcile with an escape tectonics model as predicted by scaled

102 models and observations from the indentation of India into Eurasia (Tapponnier et al., 1982).

103 A recent model for the geodynamic evolution of the ASZ (Westerhof et al. (2014)

104 explained the early stages of its development as a sinistral strike-slip shear zone associated with 105 northward escape of the Arabian-Nubian Shield and the northeastern segment of the Northern 106 Uganda terrane (shown in Figure 1B as the Saharan Metacraton) because of oblique collision 107 between East and West Gondwana. Further, Westerhof et al. (2014) proposed that the ASZ 108 subsequently witnessed an E-W extension triggered by N-S collision between the proto-Congo 109 craton and the Saharan Metacraton (Figure 1A) and that the final assembly of Gondwana allowed 110 for northwest and southeast propagation of the shear zone.

112 1.2. The lithospheric structure of the Aswa Shear Zone

113 It has been suggested that the ASZ represents the boundary between the Congo craton in 114 the southwest (represented in Uganda by the Northern Uganda terrane of Westerhof et al. (2014)) 
115 and the Saharan Metacraton to the northeast (Figure 1B; Abdelsalam et al., 2002; 2011). Seismic

116 tomography results suggested that the Saharan Metacraton has a lithospheric thickness of $\sim 100$

$117 \mathrm{~km}$ compared to the Congo craton which has a lithospheric thickness of $\sim 175-250 \mathrm{~km}$

118 (Abdelsalam et al., 2011). South of the ASZ, in the upper $100 \mathrm{~km}$ of the lithospheric column, the

119 S-wave velocity is 2 to $6 \%$ faster relative to the Primary Reference Earth Model (PREM) while it

120 is 2\% slower relative to PREM north of the shear zone (Figure 2A; Abdelsalam et al., 2011). A

121 similar pattern is also present in the $100-175 \mathrm{~km}$ depth interval of the lithosphere (Figure 2B).

122 Additionally, from a N-S S-wave velocity profile, Abdelsalam et al. (2011) have shown that the

123 northwestern continuation of the ASZ, which intersects the Oubanguide orogen (Figure 1A), has

124 a much slower S-wave velocity compared to both the Congo craton and the Saharan Metacraton

125 (Figure 2C). In addition, Craig et al. (2011) have shown that there is a sharp transition in 126 earthquake focal depths across the ASZ where the seismogenic thickness is less than $20 \mathrm{~km}$ 127 northeast of the shear zone and it is greater than $20 \mathrm{~km}$ southwest of it (Figure 2D). Craig et al. 128 (2011) also observed that this sharp transition from shallow to deep seismogenic thickness 129 coincides with a change from thin $(\sim 100 \mathrm{~km})$ lithosphere northeast of the ASZ to a thick $(\sim 175$ $130 \mathrm{~km}$ ) lithospheric southwest of the shear zone (Figure 2E).

\subsection{The Aswa Shear Zone and evolution of Mesozoic and Cenozoic rifts in eastern Africa}

Although no detailed information is available, the parallelism between the NW-trending 134 ASZ and the NW-trending Mesozoic rifts in eastern Africa, especially in South Sudan, led Daly 135 et al. (1989) to consider strain localization during the Mesozoic rifting event as being facilitated 136 by the ASZ and other related NW-trending shear zones. In contrast, relatively more research has 137 been carried out to explain the influence of the ASZ on the evolution of the Cenozoic-aged East 
African Rift System, especially its bifurcation into an Eastern and a Western Branch and the apparent termination of the Western Branch against the shear zone (Figure 3A). The bifurcation of the East African Rift System southwest of the ASZ led Chorowicz (2005) to suggest that the

141 shear zone has been reactivated as a "continental transform fault" where WNW-ESE extension 142 exerted by the east-southeast motion of the Somali plate relative to the Nubian plate (Calais et 143 al., 2006; Stamps et al., 2008; Saria et al., 2014) has been accommodated as a strike-slip motion 144 along the shear zone.

The northern segment of the Western Branch of the East African Rift System represented 146 by the Albertine-Rhino grabens sharply terminates against the ASZ (Figure 3B). However, the 147 1990-1991 earthquake events of South Sudan have been interpreted as an indication of the 148 continuation of the Western Branch further northeast beyond the Albertine-Rhino grabens 149 (Girdler and McConnell, 1994). Contrary to this suggestion, Katumwehe et al. (2015) have 150 shown from airborne magnetic data that the Albertine-Rhino grabens do not extend in a northeast 151 direction beyond the ASZ. Further, Katumwehe et al. (2015) suggested that the presence of the 152 heterogeneous and thinned lithosphere of the Saharan Metacraton that lacks well-developed pre153 existing lithospheric fabric might have prevented strain localization during the onset of rifting, 154 hence leading to the apparent termination of the Western Branch against the ASZ.

155 Some of the Cenozoic shield volcanoes associated with the development of the Eastern 156 Branch of the East African Rift System are found at or close to the intersection of the ASZ with 157 the Cenozoic structure. For example, Mt Elgon, which is found in the Elgon depression to the 158 west of the main trend of the Eastern Branch, is located along the trace of the ASZ (Fig. 3A). 159 Similarly, Mt Kilimanjaro is located at the intersection of the ASZ with NE-trending structures 
related to the Eastern Branch (Figure 3A). This led Fairhead (1980) to refer to the ASZ as the 161 "leaky transform fault".

\subsection{The Aswa Shear Zone and seismicity in eastern Africa}

The vicinity of the ASZ has been the site of seismic activities in eastern Africa (Figures

3A and C; Gaulon et al., 1992; Girdler and McConnell, 1994; Moussa, 2008; Craig et al., 2011), especially the 1990-1991 earthquakes in South Sudan. A significant number of earthquakes with magnitudes 7.2 and focal depth of 20-50 km were reported in 1990-1991 in South Sudan. Fault plane solutions from these earthquakes suggest sinistral strike-slip movement along NW-trending planes, normal-slip movement within WNW-trending planes, and oblique-slip movement within

170 WNW-trending planes (Figure 3C; Moussa, 2008; Craig et al., 2011). The normal-slip movement 171 was considered to indicate northward continuation of the East African Rift System to the 172 northeast of the ASZ (Gaulon et al., 1992; Girdler and McConnell, 1994) whereas the strike-slip 173 movement was interpreted to be associated with the reactivation of the ASZ into sinistral strike174 slip fault due to east-southeast movement of the Somali plate away from the stationary Nubian 175 plate (Moussa, 2008). The reactivation of the ASZ from ductile Precambrian structure to younger 176 brittle NW-trending fractures is also apparent in remote sensing data where morphologically177 defined structures are observed to coincide with the trace of the shear zone (Figure 4). This part 178 of the shear zone has influenced the evolution of the Nile drainage system where the NE-flowing 179 Albert Nile shifted its flowing direction by making a sharp left turn when it encountered the ASZ 180 to become the NW-flowing Bahr el Jabal (Figure 4). 


\section{Regional Geology of the Aswa Shear Zone}

The ASZ occupies an important region in the East African orogeny since it is exposed close to the interface between the Arabian-Nubian Shield in the north and the Eastern Granulite

186 belt to the south which represent part of the Mozambique belt (Figure 1B). The exposed part of 187 the shear zone in Uganda seems to separate Precambrian regions that differ in their characters. 188 The region to the southwest of the shear zone is dominated by the Northern Uganda terrane 189 (Figure 1B) which is composed of Mesoarchean granulites and Neoarchean gneisses, migmatites, 190 and granitoids (Westerhof et al., 2014; Nyakecho and Hagemann, 2014). The northern part of 191 this terrane is introduced by a largely un-deformed Neoporterozoic granitic body. Differently, the 192 region to the northeast of the ASZ is characterized by the presence of Neoproterozoic exposures 193 of banded granulites-charnockites complexes together with highly-sheared Neoproterozic 194 gneisses and granitoids, and Archean-Paleoproterozoic gneisses (Westerhof et al., 2014; 195 Nyakecho and Hagemann, 2014). Westerhof et al. (2014) concluded that the Neoproterozoic 196 granulites-charnockites complexes are tectonically emplaced and they represent three 197 allochthonous sheets referred to as the Morungole, Akur and Ukatat massif (Figure 1B). These 198 allochthonous sheets were thrust above the Archean-Paleoproterozoic gneisses. Further, 199 Westerhof et al. (2014) proposed that the source of the Neoproterozoic banded granulites200 charnockites allochtonous sheets is the deeper roots of the suture between East and West 201 Gondwana. Fritz et al. (2013), Westerhof et al. (2014) and Nyakecho and Hagemann (2014) 202 agreed that the Neoproterozoic rocks in the northeastern-most part of Uganda belong to the East 203 African orogen. Westerhof et al. (2014) referred to these exposures as the Pan-African Karamoja 204 belt (Figure 1B). 
Fritz et al. (2013) linked the evolution of the ASZ to that of the Nyangere shear zone, 206 which marks the western boundary of the Arabian-Nubian Shield (Figure 1B). Also, Fritz et al. 207 (2013) suggested that the ASZ continues to the southeast into Tanzania and merged into a NW208 trending sinistral strike slip fault referred to as the 'Jailhouse rock fault' (Figure 1B). Based on 209 regional correlation between the ASZ and the Nyangere shear zone, Fritz et al. (2013) suggested 210 that sinistral strike-slip activities in the ASZ might have commenced prior to $\sim 590 \mathrm{Ma}$. This is 211 based on cross-cutting relationships where the Nyangere shear zone is cut by an un-deformed 212 granitic body which gave a whole rock $\mathrm{Rb} / \mathrm{Sr}$ isochron age of 593+/-50 Ma (Ries et al., 1992). 213 Recently, Westerhof et al. (2014) reported U-Pb zircon ages of $\sim 2,660 \mathrm{Ma}$ and $\sim 690 \mathrm{Ma}$ from a 214 migmatite granitic body that is deformed by the ASZ and interpreted the younger age as due to 215 overprint of blasto-mylonite peak metamorphism associated with the onset of the ASZ activities. 216 Further, Westerhof et al. (2014) interpreted a U-Pb zircon age of 659+/-15 Ma obtained from an 217 elongated granitic body (2-4 km wide and $\sim 5 \mathrm{~km}$ long) that intrudes the northwestern part of the 218 ASZ to indicate the age of an extensional activity in the shear zone exerted by N-S collision 219 between the proto-Congo craton and the Saharan Metacraton.

220 Almond (1962) described the ASZ as a $\sim 6 \mathrm{~km}$ wide zone of sinistral strike-slip shearing 221 characterized by the development of mylonitic fabric that deforms older gneissic layering. 222 Almond (1962) pointed out that the gneisses across the shear zone are of different character 223 because the sinistral strike-slip movement along the shear zone brought different rock types to 224 juxtaposition. Recent observations by Ruotoistenmaki (2014) from airborne magnetic data have 225 shown that the ASZ is wider than what has been mapped from the surface geology. Westerhof et 226 al. (2014) described the ASZ as a complex zone of steeply NE and NW-dipping ductile-brittle 227 sinistral strike-slip fabric characterized by the presence of discrete blasto-mylonite high-strain 
228 zones that enclose lenses which are relatively not affected by the shearing. Westerhof et al.

229 (2014) also observed that in many places, the planar fabric of the ASZ deforms the gneisses of

230 the North Uganda terrane resulting in the transposition of the older gneissic banding leading to

231 the formation of rootless isoclinal folds. Westerhof et al. (2014) documented in some outcrops

232 the transitioning of the blasto-mylonite fabric into pseudotachylie as well as the formation of

233 boudinage structure due to the deformation of a pre-existing dolerite dike by the sinistral strike-

234 slip movement of the ASZ.

235

$236 \quad$ 3. Data and Methods

237 3.1. Airborne Magnetic Data

238 The airborne total field magnetic data we used in this study (Figure 5A) was part of a 239 2006-2009 data acquisition campaign by the Ugandan Department of Geological Survey and 240 Mines (DGSM) that covered $80 \%$ of the country. The data were collected with a flight altitude of $241 \sim 80$ meters, line spacing of $\sim 500$ meters, and a flight orientation of $\sim \mathrm{N} 55^{\circ}$. The low magnetic

242 inclination in the study area that ranges between $-14^{\circ}$ and $-22^{\circ}$ did not allow us to identify the 243 sources of the magnetic anomalies using conventional methods such as the reduction to the pole.

244 Alternatively, to highlight the general trends of the Precambrian structures through the magnetic 245 anomalies, we have extracted a horizontal derivative map from the total field magnetic data 246 (Figure 5B). The results of this edge detection filtering technique are not affected by the 247 magnetic inclination, declination or remanence (Thurston and Smith, 1997; Smith and Salem, 248 2005). Hence, because the horizontal derivative map images the edges of the magnetized bodies, 249 we were able to use the resulting magnetic fabric (Figure 5B) as a proxy for mapping regional 250 Precambrian structures 
We have developed a new method to measure the orientation of the strike and the dip amount and direction of the regional Precambrian structures from the airborne magnetic data.

253 First, we used the magnetic fabric defined by the horizontal derivative map to measure the strike 254 of the regional Precambrian structures in specific locations of the study area. Second, using the 255 technique established by Thurston and Smith (1997), Verduzco et al. (2004), Smith and Salem 256 (2005) and Salem et al. (2007) we developed a tilt derivative image by obtaining the ratio of the 257 vertical derivative to the horizontal derivative of the total field airborne magnetic data (Figure 258 5C). In this image, the tilt distribution defines the contacts between geological materials that 259 have alternating high and low magnetic susceptibility (Salem et al., 2007). The calculated tilt 260 angles range between $+90^{\circ}$ and $-90^{\circ}$ with the angle values with $(+)$ sign represent the tilt of the 261 magnetic source towards the northeast and southeast quadrants. The angle values with (-) sign 262 indicate tilt direction towards the SW and NW quadrants. Third, we extracted the tilt angles and 263 directions from the tilt derivative image for the same locations where we used the horizontal 264 derivative image to measure the strike of the magnetic fabric. This allowed us to establish strike 265 and dip dataset for the study area.

267 3.2. Airborne Radiometric Data

268 The airborne radiometric data we used in this study (Figure 5D) was simultaneously 269 acquired with the airborne magnetic data. The emission of gamma rays through radioactive 270 decay of naturally occurring radioisotopes has proven useful for mapping the boundaries of 271 geological units (Duval, 1983; Minty, 1997). Hence, gamma ray surveys have been used to 272 image the geochemical characteristics of the Earth surface and near surface to a depth of $30 \mathrm{~cm}$ 273 (Erdi-Krausz et al., 2003). The three radioisotopes that have been traditionally used for 
274 geological mapping include Potassium (K), Uranium (U) and Thorium (Th). The emission of 275 gamma rays during the decay of ${ }^{40} \mathrm{~K}$ to the stable isotope Argon $\left({ }^{40} \mathrm{Ar}\right)$ can be used to estimate 276 the amount of $\mathrm{K}$ in the geological unit. Radioisotopes ${ }^{238} \mathrm{U}$ and ${ }^{235} \mathrm{U}$ decay to stable Lead isotope $277\left({ }^{206} \mathrm{~Pb}\right)$ and $\left({ }^{207} \mathrm{~Pb}\right)$, respectively. The naturally occurring radioisotope ${ }^{232} \mathrm{Th}$ decay series ends in 278 producing isotope ${ }^{208} \mathrm{~Pb}$. The concentration of radioisotopes ${ }^{238} \mathrm{U}$ and ${ }^{232} \mathrm{Th}$ in any geological unit 279 can be indirectly estimated from the gamma ray emission of their radioactive daughter products. 280 This is because these radioisotopes do not emit gamma ray in their initial radioactive decay 281 process. Assuming that the radioactive daughter products of radioisotopes ${ }^{238} \mathrm{U}$ and ${ }^{232} \mathrm{Th}$ are 282 under equilibrium, the concentration of the two radioisotopes can be estimated as the equivalents $283 \mathrm{eU}$ and eTh in parts per million (ppm).

284 After removing the noise from the airborne radiometric data using the noise-adjusted 285 value decomposition method, we used the minimum curvature gridding algorithm (Briggs, 1974; 286 Grasty, 1997; Minty and McFadden, 1998) to obtain K, eTh, eU concentrations from the 287 airborne radiometric data with a grid cell spatial resolution of $50 \mathrm{~m}$. Subsequently, we created a 288 ternary image by assigning the $\mathrm{K}$ concentration to red, the eTh concentration to green, and the 289 eU concentration to blue (Figure 5D). Areas with high concentration in all three radioisotopes 290 appear white in the ternary image. Differently, areas that lack concentration of all radioisotopes 291 appear black as in the case of water bodies (Figure 5D). The color yellow in the ternary image is 292 indicative of high $\mathrm{K}$ and Th concentration, magenta reflects high concentration of $\mathrm{K}$ and $\mathrm{U}$, 293 whereas cyan manifests high Th and U concentration. 


\section{Results}

\subsection{The Extent of the Aswa Shear Zone}

The SRTM DEM enabled us to map the extent of the ASZ in Uganda and South Sudan

300 for over $\sim 550 \mathrm{~km}$ extending from longitude $30^{\circ} 20^{\prime} \mathrm{E}$ and latitude $5^{\circ} 20^{\prime} \mathrm{N}$ in the northwest to 301 longitude $33^{\circ} 30^{\prime} \mathrm{E}$ and latitude $2^{\circ} 10^{\prime} \mathrm{N}$ in the southeast (Figure $6 \mathrm{~A}$ ). In the northwest, the shear 302 zone bifurcates into a number of NW-trending splays before disappearing under what seems to 303 be unconsolidated sediments (Figure 6A). To the southeast, in Uganda the trace of the shear zone 304 disappears under the volcanic pile of Mt Elgon (Figure 3A). In Uganda, the SRTM DEM shows 305 the shear as a single linear trend that persists in a NW-SE direction for $\sim 250 \mathrm{~km}$ (Figure $6 \mathrm{~A}$ ).

The surface expression of the ASZ is more apparent in South Sudan where the 307 southeastern end of the shear zone is dominated by what appears to be tight folds that lie sub308 parallel to the prominent trend of the shear zone itself (Figure 6B). The central part of the shear 309 zone in South Sudan is characterized by the presence of splays of regional fabric originating 310 from the main trace of the shear zone resulting in the presence of $\mathrm{N}$ and NE-trending structures 311 (Figure 6C). Although the ASZ in Uganda has a limited surface expression observable in the 312 SRTM DEM, the airborne total field magnetic image revealed it as a much wider structure 313 similar to its extent in South Sudan (Figure 6D).

314 Extraction of structural lineation from the horizontal derivative (Figure 5B) and the 315 ternary image (Figure 5D) revealed a more complicated picture of the ASZ in Uganda (Figure 316 7A) than what is apparent in the SRTM DEM. This image shows that the ASZ is characterized 317 by the presence of three branches that are separated from each other with distances ranging 318 between 5 and $30 \mathrm{~km}$ (Figure 7A). Here, we refer to these branches as the northeastern ASZ, 319 central ASZ, and southwestern ASZ (Figure 7A). The central ASZ corresponds to the exposed 
320 part of the shear zone that is traced from the SRTM DEM as a single linear feature (Figure 6A).

321 This branch of the shear zone is also distinct in the ternary image by its bright to white color

322 indicating high $\mathrm{K}$, Th and $\mathrm{U}$ concentrations (Figure 5D). The northeastern ASZ exhibits a 323 curvilinear pattern by changing orientation from NW-trending in the northwest to N-trending in 324 the central part and back to NW-trending in its southeastern end (Figure 7A). This branch seems 325 to separate a domain of variable $\mathrm{K}$, Th and $\mathrm{U}$ concentrations in the southwest from a domain 326 with no specific radiometric concentration in the northeast (Figure 5D). The southwestern ASZ is 327 less obvious in the ternary image suggesting that it does not separate two distinct lithologies 328 (Figure 5D). However, this branch is more apparent in the horizontal derivative image because it 329 separates domains with different orientations of the magnetic fabric (Figures 5B and 7A). The 330 domain in the southwest is dominated by magnetic lineation that defines N-trending broad open 331 folds (Figures 5B and 7A). On the other hand, the domain that is bounded by the southwestern 332 and the central ASZ is characterized by sigmoidal N-S-trending magnetic fabric sometimes 333 defined by what appears to be tight folds (Figures 5B and 7A).

334 The region to the northeast of the ASZ is dominated by well-defined and strong linear 335 magnetic fabric that we interpret as indicating the presence of at least two major structural 336 boundaries (Figures 5B and 7A). These two boundaries bound a funnel-shaped region shown by 337 cyan color in the ternary image indicative of high Th and $U$ concentration (Figure 5D). This is 338 followed further northeast by a domain that lacks any significant magnetic fabric (Figure 5B) 339 with either Th or no radioisotopes concentrations as indicated by its green to black color in the 340 ternary image (Figure 5D). 


\subsection{Kinematics of the Aswa Shear Zone}

344 4.2.1. Sense and amount of displacement along the Aswa Shear Zone

Ruotoistenmaki (2014) used offsets of magnetic anomaly to suggest $\sim 60 \mathrm{~km}$ horizontal

346 sinistral strike-slip movement along the ASZ. The displacement of a similar magnetic anomaly to

347 the northwest of the one that was measured by Ruotoistenmaki (2014) also gave $\sim 60 \mathrm{~km}$

348 horizontal displacement (Figure 5B). Additionally, a similar amount of horizontal sinistral strike-

349 slip displacement has been observed from drag features related to the shear zone that appear in 350 the SRTM DEM in South Sudan (Figure 3B).

\subsubsection{Structural complexity of the Aswa Shear Zone}

The strike and dip of the magnetic fabric defining the ASZ and surrounding structures extracted from the airborne magnetic data were used to outline the three-dimensional (3D) geometry of these structures. For this, we established a number of structural domains that are separated by the three branches of ASZ as well as the two additional localized deformation zones 357 to the northeast (Figure 7A). Subsequently, to analyze the dominant orientation of the 358 deformation zones, the strike and dip of the magnetic fabric along the entire length of each 359 boundary were plotted as poles to planar fabric in equal area stereonet (Figure 7B-F). 360 Additionally, to analyze the geometry of the structures dominating the domains between the 361 deformation zones, the magnetic fabric from these domains were plotted as poles to planar fabric 362 in equal area stereonet (Figure 7G-K).

363 We drew the following observations from these plots:

364 1) The three branches of the ASZ (Figure 5A) show a consistent pattern of stereonets 365 indicative of the presence of sub-horizontal NW-SE trending fold axes (Figure 7B-D). 366 Assuming that the magnetic fabric defines the regional NW-trending, steeply NE and 
SW-dipping mylonitic fabric associated with the sinistral strike-slip shearing of the ASZ as observed by Westerhof et al. (2014), our results suggest that the mylonitic planar fabric itself has been subsequently folded. This is consistent with field observations from outcrops where re-folding of the mylonitic fabric is apparent (Figure 7A; Almond, 1962). This in turn suggests a strong role of an E-W to NE-SW contraction component in the development of the ASZ.

2) The stereonet plot in the localized deformation zone to the northeast of the northeastern ASZ does not support the presence of NW-SE trending folding of the magnetic fabric (Figure 7E). Rather, the plot suggests the presence of shallow to moderately dipping to the northeast planar fabric within the localized deformation zone. Farther to the northeast, the magnetic fabric from the northeastern-most deformation zone produced a stereonet plot that lacks clear presence of any preferred orientation of the planar fabric. (Figure 7F). This deformation zone bounds a region in the east that lacks obvious magnetic lineation possibly due to the presence of sub-horizontal magnetic fabric (Figure 5B). Comparing the airborne magnetic images with the geological map of Westerhof et al. (2014) and Nyakecho and Hagemann (2014) revealed that this region is dominated by one of the Neoproterozoic banded granulites-charnockites complexes that structurally underlain by the highly-sheared Neoproterozoic gneisses and granitoids. The Neoproterozoic banded granulites- charnockites complex fall within the northwestern along-strike continuation of the Eastern Granulite belt which is better defined in Tanzania and Kenya (Figure 1B). This belt is interpreted as dominantly $\mathrm{W}$-verging nappe (Fritz et deformation zones to the northeast of the ASZ to represent W-verging thrusts where the 
highly-sheared Neoproterozoic gneisses and granitoids on the one hand and the granulites-charnockites complex on the other hand were thrust westward over the Archean-Paleoproterozoic gneisses. This observation further reinforces the notion that a strong E-W to NE-SW contraction component played a significant role in the final architecture of the ASZ.

3) The domain to the southwest of the southwestern ASZ is characterized by the presence of open folds defined by NW and NE-trending magnetic fabric (Figures 5B and 7A). Plotting the poles of the magnetic fabric in equal area stereonet indicates that the fold axis is shallowly plunging to the south-southeast (Figure 7G). Westerhof et al. (2014) documented that these open fold are younger Neoproterozoic structure that refolded the planar fabric and isoclinal folds of the older Archean rocks of the Northern Uganda terrane.

4) The stereonets of the domains bounded by the three branches of the ASZ show a common pattern indicating folding about NW-SE trending axes (Figure 7H-J). One example of these folds is found within the domain that is bounded by the southwestern and central ASZ where the magnetic fabric defines what appears to be a tight NW-SE trending fold (Figure 8A). This is similar to the fold geometry observed in the SRTM DEM $\sim 150 \mathrm{~km}$ to the northwest (Figure 8B). The axial traces of these folds (as estimated from the magnetic fabric and SRTM DEM) are at slight angle to the NW-trend of the ASZ. This suggests the development of these folds as due to secondary ENE-WSW contraction component associated with the overall sinistral strike-slip movement on the NW-trending planes of the shear zone. 
5) The plot of poles to the magnetic fabric from the domain to the northeast of the ASZ doesn't seem to define any particular $\pi$-circle in the equal area stereonet (Figure $7 \mathrm{~K}$ ). This might be due to superimposition of more than one folding event since this domain is bounded by curved boundaries that have been interpreted as W-verging thrusts.

\section{Discussion - Understanding the Tectonic Origin of the ASZ}

We outline observations that are important for understanding the tectonic origin of the

ASZ. (1) Our results show that the mylonitic fabric which was developed due to sinistral strike-

420 slip shearing was subsequently refolded (Figure 7B-D). The sterenets in Figures 7B-D show

421 folding of the planar fabric about NW-SE axes indicating that an E-W to NE-SW contraction

422 component is recorded throughout the region. (2) Our results also show that the domains

423 bounded by the three branches of the ASZ are dominated by NW-SE trending folds (Figure 7G-

424 J). (3) Our observations agree with those of Westerhof et al. (2014) in that the region to the

425 northeast of the ASZ is dominated by W-verging thrusts where Neoproterozoic banded

426 granulites- charnockites complexes form allochthonous units overlying highly-sheared

427 Neoproterozoic gneisses and granitoids which themselves overly Archean-Paleoproterozoic

428 gneisses. (4) Farther east, along the Uganda-Kenya border, previous studies documented the

429 presence of a heterogeneous W-verging nappe consists of Neoproterozoic granulites, granitic 430 gneisses, amphibolite, quartzites and marbles (Figure 9A) and these lithologies have been

431 referred to by Westerhof et al. (2014) as the Pan-African Karamoja belt. This nappe represents 432 the western margin of the Arabian-Nubian Shield as evidenced by the presence of Sekerr 433 ophiolite found in Kenya just to the east (Figure 1B; Fritz et al., 2013).. 
The observations above indicate the presence of a strong E-W to NE-SW contraction component that has affected this part of the East African Orogen, the Saharan Metacraton, and

436 the Northern Uganda terrane. We attribute this contraction to E-W to NE-SW oblique collision

437 between East and West Gondwana. This interpretation is in good agreement with a model 438 previously proposed by Westerhof et al. (2014) to explain the early stages of the development of 439 the ASZ. The collision obliquity must have had contributed to the partitioning of strain into E-W 440 to NE-SW contraction and NW-trending sinistal strike-slip component. Hence, we suggest that 441 the oblique collision resulted in the development of W-verging nappes on the eastern edge of the 442 Saharan Metacraton, and these nappes represent part of the Arabian-Nubian Shield (Figure 9B).

443 The collision also resulted in the westward emplacement of the Neoproterozoic banded 444 granulites-charnockites complexes onto the Archean-Paleoproterozoic gneisses of the Saharan 445 Metacraton (Figure 9B). To the west, the collision was accommodated as dominantly sinistral 446 strike-slip movement accompanied by E-W to NE-SW contraction. It is possible that the strain 447 localization within the ASZ was facilitated by the presence of a pre-existing boundary between 448 the Saharan Metacraton and the Northern Uganda terrane.

449 Fritz et al. (2013), from regional geologic correlation, considered the ASZ to be active 450 prior to $\sim 590 \mathrm{Ma}$. However, U-Pb zircon ages obtained by Westerhof et al. (2014) suggest that 451 the Neoproterozoic activities of the ASZ might have been between $\sim 690$ and $\sim 660 \mathrm{Ma}$. The 690$452660 \mathrm{Ma}$ age of the ASZ activities seems to be older than the 640-560 Ma timing of activities of 453 the Najd fault system in the northern part of the Arabian-Nubian Shield (Stern, 1994). Hence, 454 although the orientation and kinematics similarities between the ASZ and the Najd fault system 455 (both are regional NW-trending sinistral strike-slip shear zones) is tempting to suggest a 456 common origin for the two structures within the Neoproterozoic collisional tectonics between 
457 East and West Gondwana, the age difference might suggest separate evolutionary development 458 for them.

\section{$460 \quad$ 6. Conclusions}

462 covering Uganda and South Sudan allowed tracing the Precambrian ASZ for over $550 \mathrm{~km}$ in a 463 NW-SE direction with a width of $\sim 50 \mathrm{~km}$ in Uganda. Unlike its exposed part in Uganda, the 464 airborne geophysical data revealed three branches of the shear zone which bound structural 465 domains characterized by the presence of secondary shear zones and shear-related folds. The 466 shear-related folds are also apparent in the SRTM DEM covering South Sudan. Both the airborne 467 geophysical data and the SRTM DEM indicate that the ASZ is a sinistral strike-slip system with $468 \sim 60 \mathrm{~km}$ horizontal displacement. The region to the northeast of the shear zone in Uganda is 469 dominated by magnetic fabric indicating the presence of $\mathrm{W}$-verging nappes. The folding of 470 magnetic fabric defining the ASZ about NW-SE trending axis, presence of NW-SE folds within

471 the structural terrains bounded by the shear zone branches, and the presence of $\mathrm{W}$-verging 472 nappes to the northeast of the shear zone all indicate a strong E-W to NE-SW contraction 473 component that played an important role in the evolution of the shear zone. This contraction 474 component is possibly related to Neoproterozoic E-W to NE-SW oblique collision between East 475 and West Gondwana. This collision resulted in the development of the ASZ as a NW-trending 476 sinistral strike-slip and E-W to NE-SW contraction belt between the Archean-Paleoproterozoic 477 crusts of the Saharan Metacraton in the northeast and the Northern Uganda terrane to the 478 southwest. This collision also resulted in the emplacement of the W-verging nappes of the 
479 Arabian-Nubian Shield and the Eastern Granulite belt emplaced on the eastern edge and atop the 480 Saharan Metacraton, respectively.

481

482 Acknowledgements

483 We thank the Government of Uganda for allowing us free access to the airborne magnetic 484 and radiometric data. This study was financially supported by the National Science Foundation 485 Continental Dynamics grant \# EAR 1255233. We thank two anonymous reviewers for detailed 486 comments and associate editor A. Collins for handling the manuscript. This is Oklahoma State 487 University Boone Pickens School of Geology contribution number 2014- 15. 


\section{References}

490 Abdelsalam, M. G., Stern, R. J., 1991. Comments and Reply on “Ophiolites in northeast and east 491 Africa: implication for Proterozoic crustal growth”. Journal of the Geological Society, London 148, 600-606.

493 Abdelsalam, M.G., Liégeois, J.P., Stern, R.J., 2002. The Saharan Metacraton. Journal of African 494 Earth Sciences 34, 119-136.

495 Abdelsalam, M.G., Gao S.S., Liégeois J.P., 2011. Upper mantle structure of the Saharan 496 Metacraton, Journal of African Earth Sciences 60, 328-336.

497 Almond D. C., 1962. Explanation of the Geology of Sheet 15 (Kitgum). Geological Survey of $498 \quad$ Uganda Report number 8, 55p.

499 Berhe, S.M., 1990. Ophiolites in Northeast and East Africa: implications for Proterozoic crustal 500 growth. Journal of the Geological Society, London 147, 41-57.

501 Briggs, I.C., 1974. Machine contouring using minimum curvature. Geophysics 39, 39-48.

502 Burke, K., Sengör, C., 1986. Tectonic escape in the evolution of the continental crust. 503 Geodynamics Series 14, 41-53.

504 Calais, E., Ebinger C., Hartnady C., Nocquet J.M., 2006. Kinematics of the East African Rift 505 from GPS and earthquake slip vector data. Geological Society of London Special $506 \quad$ Publications 259, 9-22.

507 Chorowicz, J., 2005. The East African Rift System. Journal of African Earth Sciences 43, 379508 410. 
Collins, A.S., Fitzsimons, I.C.W., Hulscher, B., Razakamanana, T., 2003. Structure of the eastern margin of the East African Orogen in central Madagascar. Precambrain Reseaarch 123, $111-133$.

Craig, T. J., Jackson, J. A., Priestley, K., McKenzie, D., 2011. Earthquake distribution patterns in Africa: their relationship to variations in lithospheric and geological structure, and their rheological implications. Geophysical Journal International 185, 403-434.

Daly, M., Chorowicz, J., Fairhead, J., 1989. Rift basin evolution in Africa: the influence of reactivated steep basement shear zones. Geological Society of London Special Publications 44, 309-334.

Duval, J., 1983. Composite color images of aerial gamma-ray spectrometric data. Geophysics 48, $722-735$.

Erdi-Krausz, G., Matolin, M., Minty, B., Nicolet, J.-P., Reford, W.S., Schetselaar, E., 2003. Guidelines for radioelement mapping using gamma-ray spectrometry data. International Atomic Energy Agency Publication IAEA-TECDOC-1363, Vienna, Austria, 173 p.

Fairhead, J.D., 1980. The structure of the cross-cutting volcanic chain of northern Tanzania and its relation to the East African Rift System.Tectonophysics 65, 193-208.

Fernandez-Alonso, M. ,Cutten, H, De Waele, B., Tack, L., Tahona, A., Baudet, D., Barritt, S.D., 2012. The Mesoproterozoic Karagwe-Ankole Belt (formerly the NE Kibara Belt): The result of prolonged extensional intracratonic basin development punctuated by two short-lived far-field compressional events. Precambrian Research 216, 63-86.

Fritz, H., Abdelsalam, M.G., Ali, K.A., Bingen, K.A., Collins, A.S., Fowler, A.R., Ghebreab, W., Hauzenberger, C.A., Johnson, P.R., Kusky, T.M., Macey, P., Muhongo, S., Stern, R.J., Viola, G., 2013. Orogeny style in the East African Orogen: A review of the 
Neoproterozoic to Cambrian tectonic evolution. Journal of African Earth Sciences 86, 65106.

534 Gaulon, R., Chorowicz, J., Vidal, G., Romanowicz, B., Rouit, G., 1992. Regional geodynamic 535 implications of the May-July 1990 earthquake sequence in southern Sudan. $536 \quad$ Tectonophysics 209, 87-103.

537 Girdler, R. W., McConnell, D. A., 1994. The 1990 to 1991 Sudan earthquake sequence and the 538 extent of the East African Rift System. Science 264, 67-70.

539 Grasty, R.L., 1997. Radon emanation and soil moisture effects on airborne gamma-ray 540 measurements. Geophysics 62, 1379-1385.

541 Katumwehe, A. B., Abdelsalam, M.G., Atekwana, E.A., 2015. The role of pre-existing 542 Precambrian structures in rift evolution: The Albertine and Rhino Grabens, Uganda. $543 \quad$ Tectonophysics. doi.org/10.1016/j.tecto.2015.01.022.

544 Meert, J.G., Lieberman, B.S., 2008. The Neoproterozoic assembly of Gondwana and its 545 relationship to the Ediacaran-Cambrian radiation. Gondwana Research 14, 5-21.

546 Minty, B., 1997. Fundamentals of airborne gamma-ray spectrometry. AGSO Journal of $547 \quad$ Australian Geology and Geophysics 17, 39-50.

548 Minty, B., McFadden, P., 1998. Improved Noise adjusted singular deconvolution (NASVD) 549 smoothing of airborne gamma-ray spectra. Exploration Geophysics 29, 516-523.

550 Moussa, H.H.M., 2008. Spectral P-wave magnitudes, magnitude spectra and other source parameters for the 1990 southern Sudan and the 2005 Lake Tanganyika earthquakes.

553 Nyakecho, C., Hagemann S., 2014. An overview of gold systems in Uganda. Australian Journal $554 \quad$ of Earth Sciences 61, 59-88. 
Pradeepkumar, A. R. Krishnanath (2000). A Pan-African 'humite epoch' in East Gondwana: implications for Neoproterozoic Gondwana geometry. Journal of Geodynamics 29, 4362.

Ries, A., Vearncombe, J., Price R.C., Shackleton R.M., 1992. Geochronology and geochemistry of the rocks associated with a late Proterozoic ophiolite in West Pokot, NW Kenya. Journal of African Earth Sciences 14, 25-35.

Ruotoistenmäki, T., 2014. Geophysical characteristics of Aswa shear, Nakasongola discontinuity and ring dyke complex in Uganda. Journal of African Earth Sciences 93, 23-41.

Salem, A., Williams, S., Fairhead, J.D., Ravat, D., Smith, R., 2007. Tilt-depth method: A simple depth estimation method using first-order magnetic derivatives. The Leading Edge 26,

Santosh, M., Collins, A.S., 2003. Gemstone mineralization in the Palghat-Cauvery Shear Zone

Smith, R.S., Salem, A., 2005. Imaging depth, structure, and susceptibility from magnetic data:

572 Stamps, D.S., Calais, E., Saria, E., Hartnady, C., Nocquet, J.-M., Ebinger, C.J., Fernandes, R.M., 573 2008. A kinematic model for the East African Rift. Geophysical Research Letters 35,

575 Stern, R.J., 1994. Arc-assembly and continental collision in the Neoproterozoic African orogen: implications for the consolidation of Gondwanaland. Annual Review of Earth and Planetary Sciences 22, 319-351. 
578 Tack, L., Wingate, M.T.D., De Waele, B., Meert, J., Belousova, E., Griffin, B., Tahon A.,

579 Fernandez-Alonso, M., 2010. The 1375 Ma "Kibaran Event" in Central Africa: prominent 580 emplacement of bimodal magmatism under extensional regime. Precambrian Research

$581 \quad 180,63-84$.

582 Tapponnier, P., Peltzer, G., Le Dain, A., Armijo, R., Cobbold, P., 1982. Propagating extrusion 583 tectonics in Asia: New insights from simple experiments with plasticine. Geology 10, 584 611-616.

585 Thurston, J., Smith, R., 1997. Automatic conversion of magnetic data to depth, dip, and $586 \quad$ susceptibility contrast using the Source parameter imaging method. Geophysics 62, 807813.

588 Verduzco, B., Fairhead, J.D., Green, C.M., MacKenzie, C., 2004, New insights into magnetic 589 derivatives for structural mapping: The Leading Edge 23, 116-119.

590 Westerhof, A.B.P., Harma, P., Isabirye, E., Katto, E., Koistinen, T., Kuosmanen, E., Lehto, T., 591 M.I. Lehtonen, M.I., Makitie, H., Manninen, T., Manttari, I., Pekkala, Y., Pkki, J., 592 Saalmann, K., Virransalo, P., 2014. Geology and geodynamic development of Uganda 593 with explanation of the 1:1,000,000 scale geological map. Geological Survey of Finland 594 Special

Paper

55 , 387p. 


\section{Figure Caption}

597 Figure 1: (A) The Arabian-Nubian Shield and the Mozambique belt representing the East African orogen between East and West Gondwana. Modified after Meert and Lieberman (2008). $\mathrm{M}=$ Madagascar. WA $=$ West Africa Craton. $\mathrm{S}=$ Saharan Metacraton. $\mathrm{C}=$ Congo Craton. $\mathrm{K}=$ Kalahari Craton. AS = Aswa Shear Zone. NF = Najd Fault System. $\mathrm{RS}=$ Ranotsara shear zone. ACS = Achankovil shear zone. The NW-trending shear zones are from Berhe (1990) and Stern (1994). (B) Precambain tectonic map of eastern Africa. Modified from a compilation by Katumwehe et al. (2015). Dotted yellow lines approximate the boundaries suggested by Westerhof et al. (1014) to divide the Northeastern Congo block in Uganda into the Western Nile terrane (WNT), Northern Uganda terrane (NUT), Lake Victoria terrane (LVT) and West Tanzania terrane (WTT). ANS $=$ Arabian-Nubian Shield. GT $=$ Galana terrane. EGB $=$ Eastern Granulite belt. SO

Figure 2: Lithophesheric structure of the Aswa Shear Zone. (A) and (B) Shear wave velocity anomalies beneath eastern and central Africa at 0-100 km and 100-175 km depth, respectively. (C) N-S S-wave velocity profiles acros the Aswa Shear Zone along longitude $20^{\circ} \mathrm{E}$ at $0-100$ and $100-175 \mathrm{~km}$ depth. (A) (B) and (C) are adopted from Abdelsalam et al. (2011). (D) Depth distribution of earthquake foci across the Aswa Shear Zone. Grey $=0-9 \mathrm{~km}$. Violet $=10-19 \mathrm{~km}$. Yellow $=20-29 \mathrm{~km}$. Red $=$ Greater than $30 \mathrm{~km}$. (E) Lithophseric thickness variation across the Aswa Shear Zone. Figures (D) and (E) are adopted from Craig et al. (2011). 
Figure 3: (A) Shuttle Radar Topography Mission (SRTM) Digital Elevation Model (DEM) showing the bifurcation of the East African Rift System into the Eastern and Western Branches southwst of the Aswa Shear Zone. (B) SRTM DEM showing the Western Branch represented by the Albertine-Rhino grabens terminating against the Aswa Shear Zone. (C) Fault plane solutions of earthquakes occurred along the Aswa Shear Zone from Mousa (2008) and Craig et al. (2011). Red = Compressional stress. White $=$ Tensile stress.

Figure 4: A 7-4-2 Landsat Thematic Mapper (TM) image showing the reactivation of the Precambrain ductle structure of Aswa Shear Zone to younger brittle and

Figure 5: Airborne geophysical data of northeastern Uganda. (A) Total field magnetic image. (B) Horizontal derivative magnetic image. (C) Tilt derivative magnetic image. (D) Ternary

Figure 6: (A) Trajectories of the main structural trends of the Aswa Shear Zone in Uganda and South Sudan extracted from the interpretation of Shuttle Radar Topography Mission (SRTM) Digital Elevation Model (DEM). (B) SRTM DEM showing tight NW-SE

Figure 7: (A) Structural trajectories of the Aswa Shear Zone and surrounding domains and deformation belts in Uganda extracted from the horizontal derivative image in Figure 5B. 
(B-K) Plot of poles to magnetic fabric in equal area stereonets with contouring interval at $1 \%$ per unit area. (B-D) $\pi$-diragrams from the three branches of the Aswa Shear Zone showing folding around NW-SE trending axis. (E) Plot of planar magnetic fabric from the deformation belt northeast of the Aswa Shear Zone indicating shallowly-dipping to planar fabric. (G) $\pi$-diragram of the domain southwest of the Aswa Shear Zone showing

Figure 9: (A) Geological map of the Aswa Shear Zone and the surrounding structures in

Figure 8: Horizontal derivative image from the domain bounded by the central and southwestern branched of the Aswa Shear Zone in Uganda (A) and Shuttle Radar Topography Mission (SRTM) Digital Elevation Model (DEM) from Aswa Shear Zone in South Sudan (B) showing NW-SE trending folds. See Figure 6 for location. northeast Uganda generated from the structual analysis of airbone geophysical data and geological maps published by Westerhof et al. (2014) and Nyakecho and Hagemann (2014) showing distribution of different lithological units. (B) Three-dimensional (3D) diagram illustrating the evolution of the Aswa Shear Zone as a NW-trending sinistral strike-slip shear zone due to E-W to NE-SW contraction that accompanied Neoproterozoic oblique collision between East and West Gondwana. 

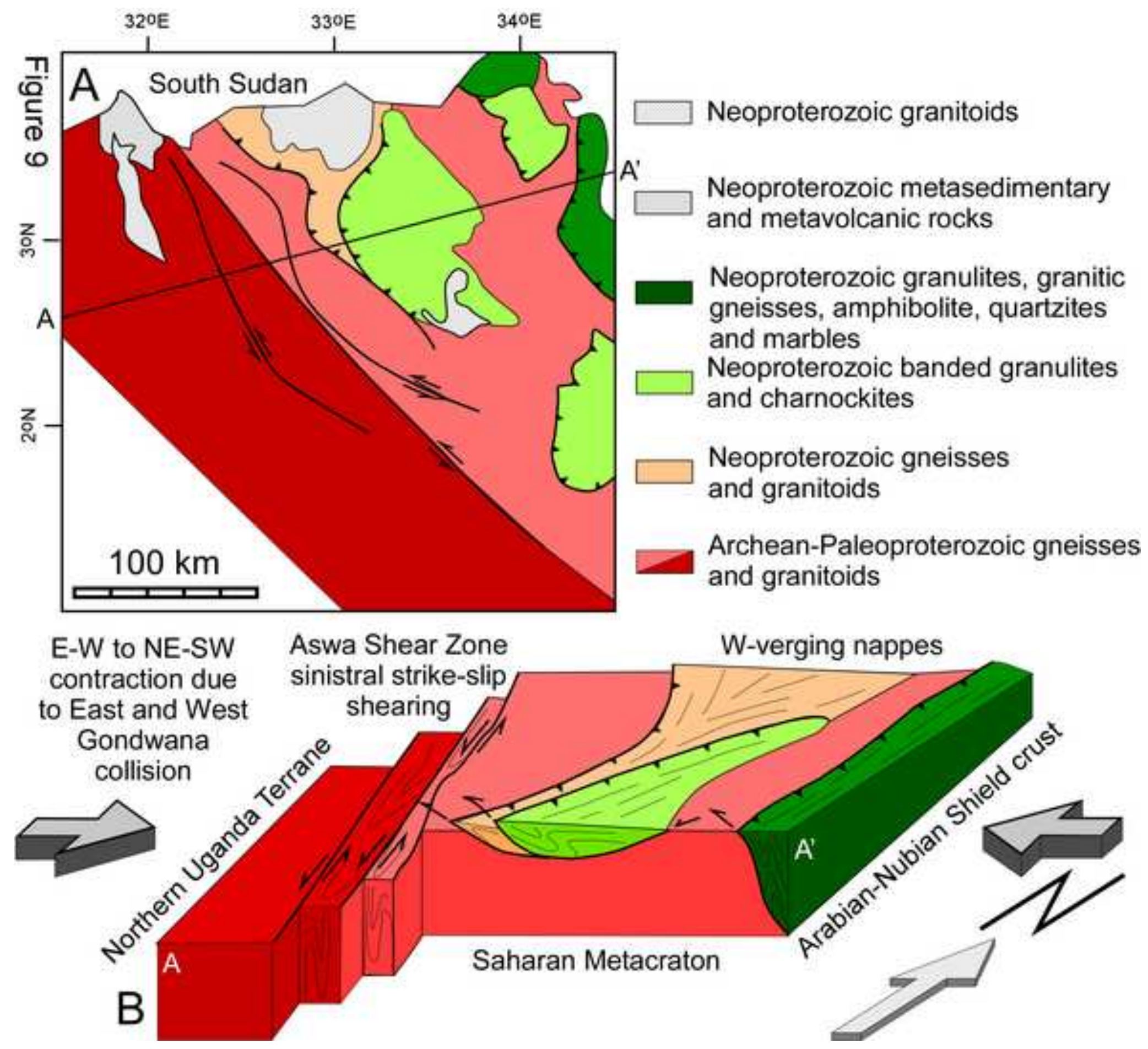

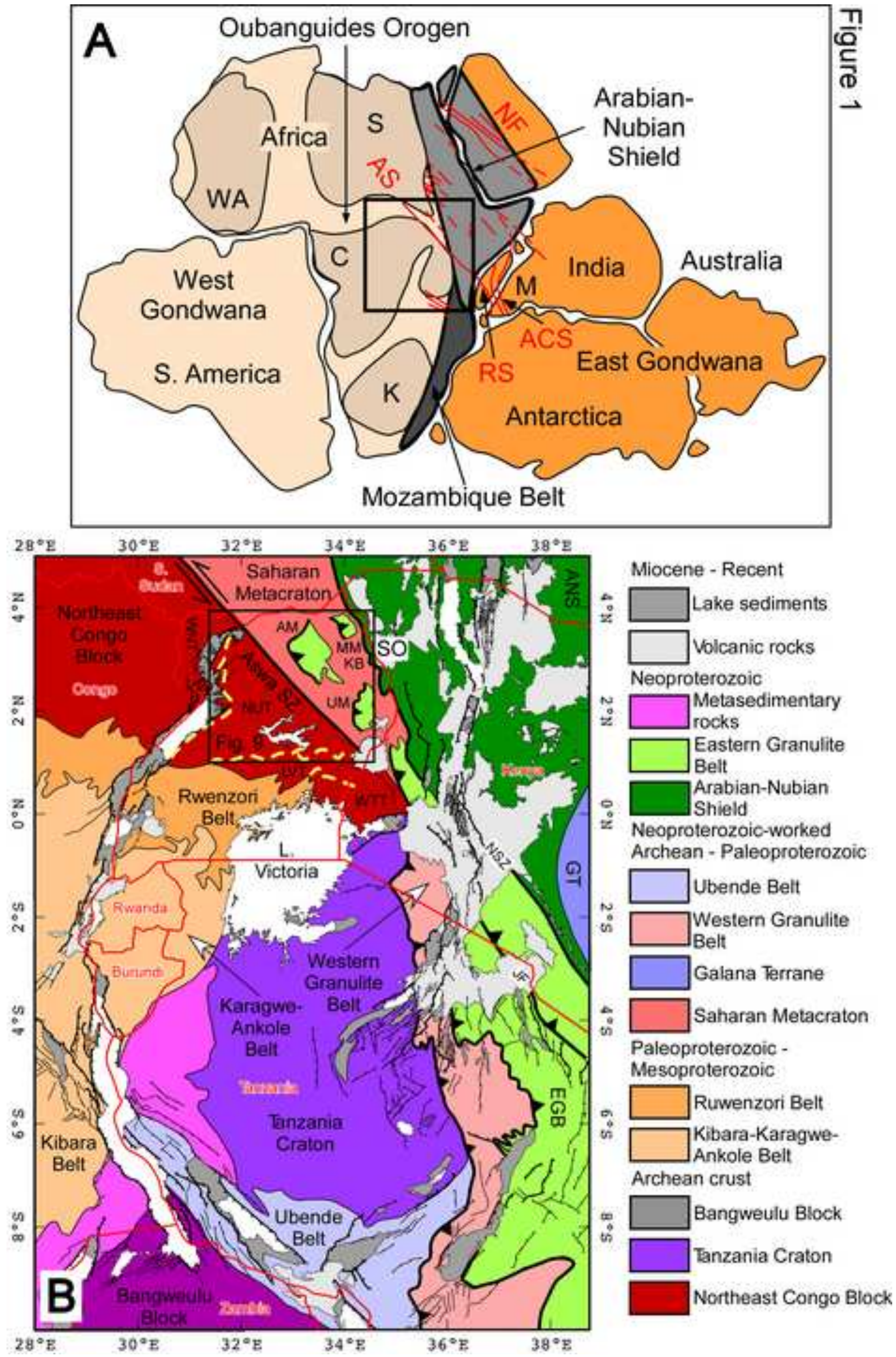

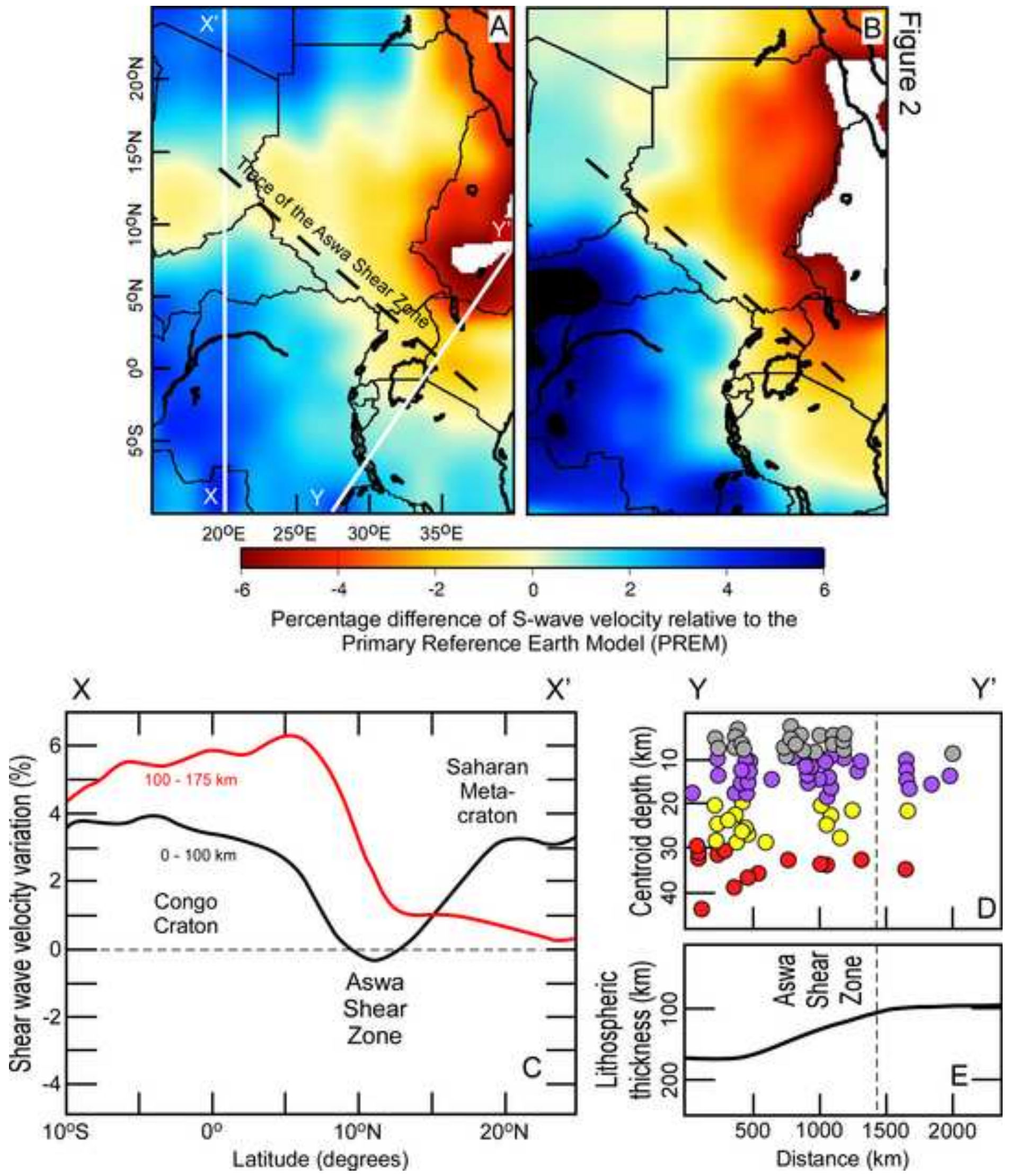

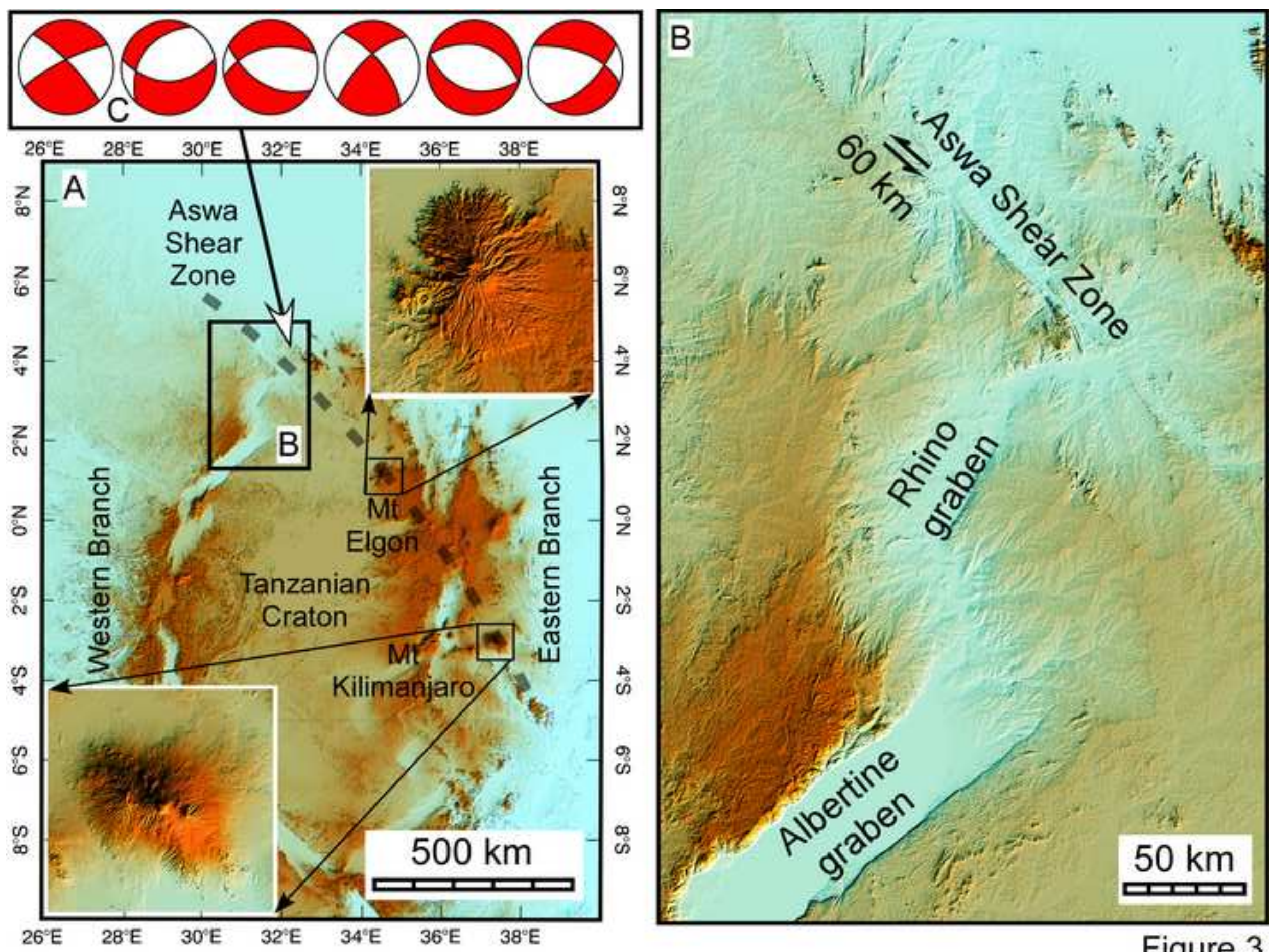

Figure 3 


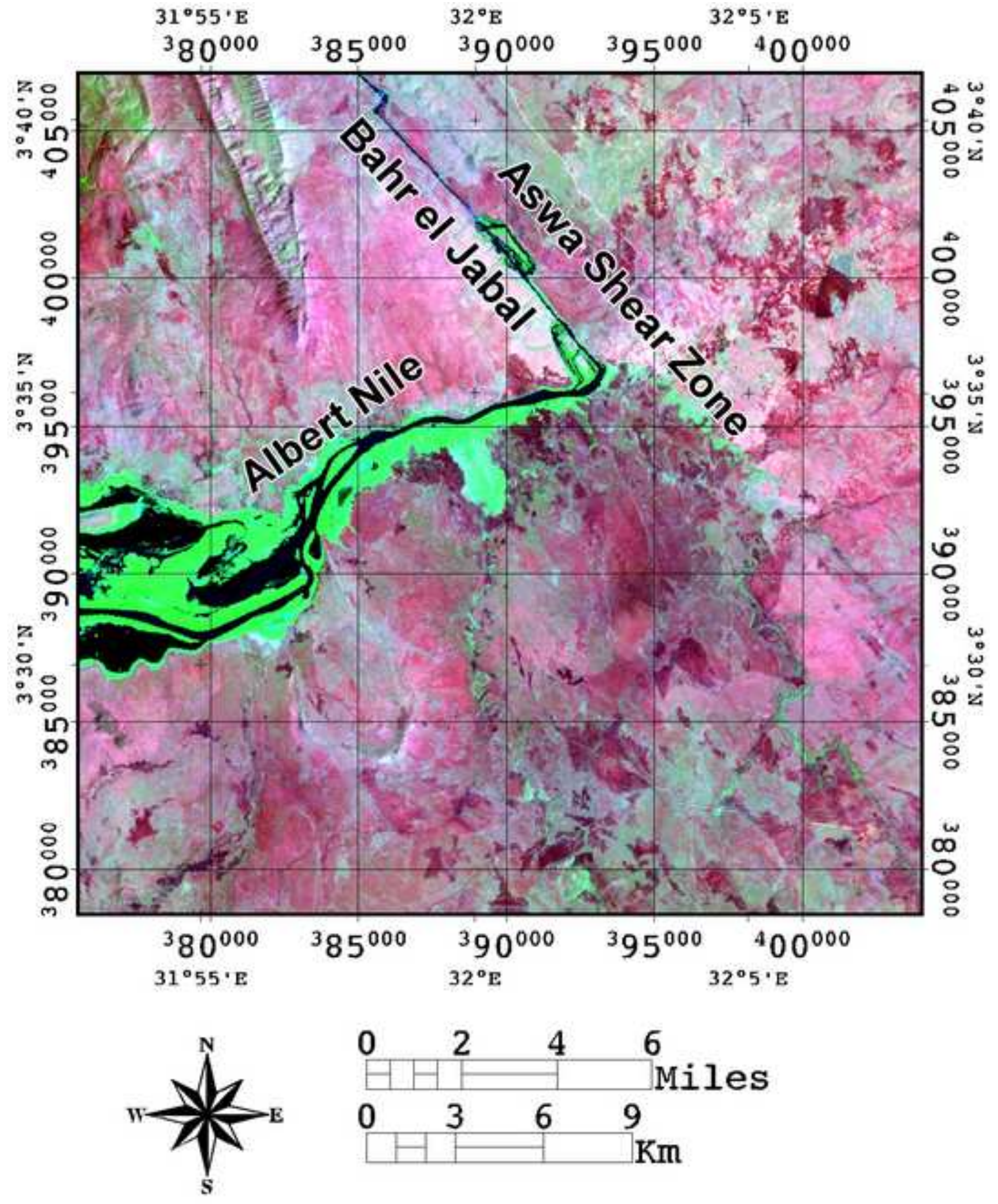

Figure 4 

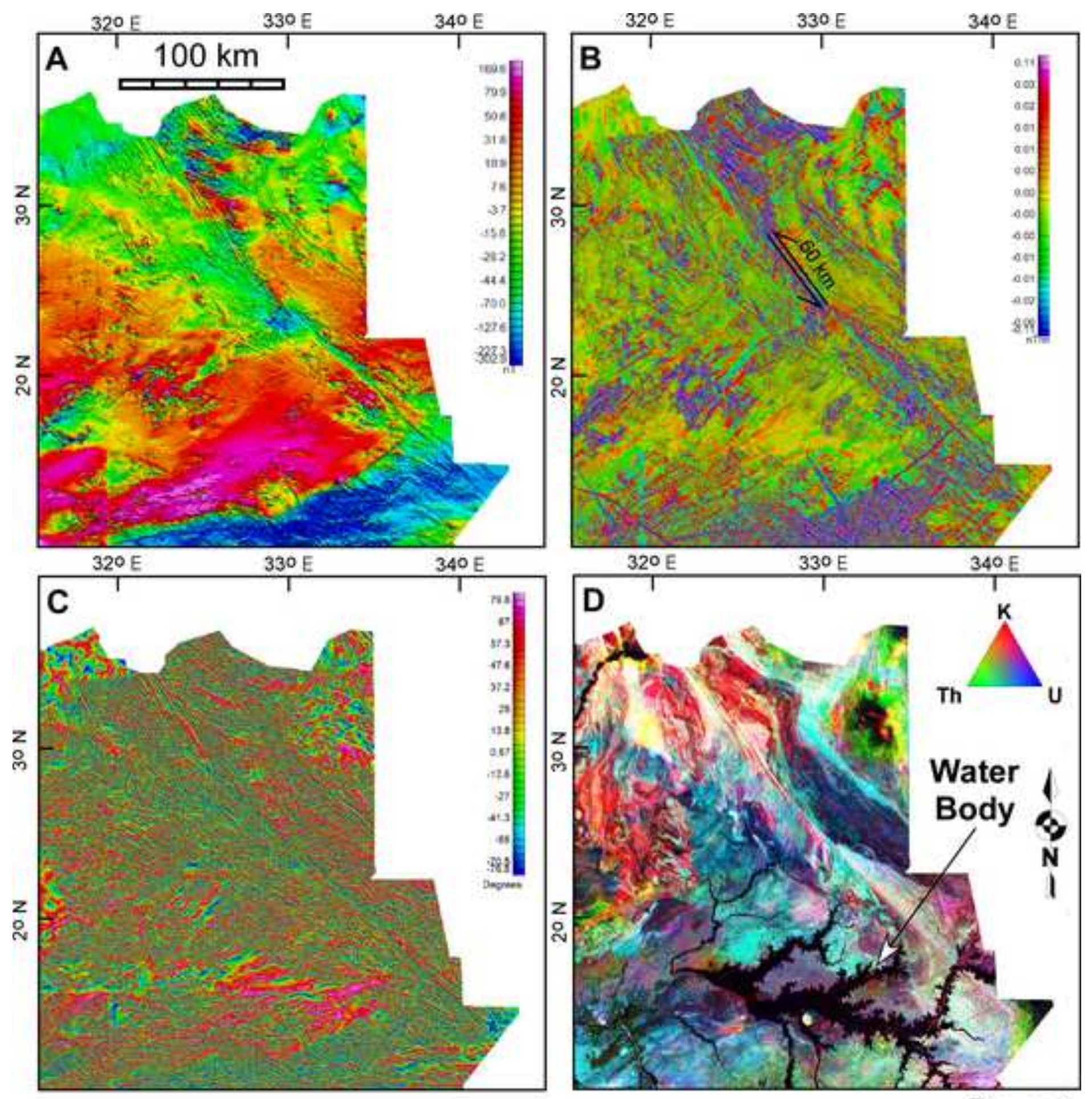

Figure 5 

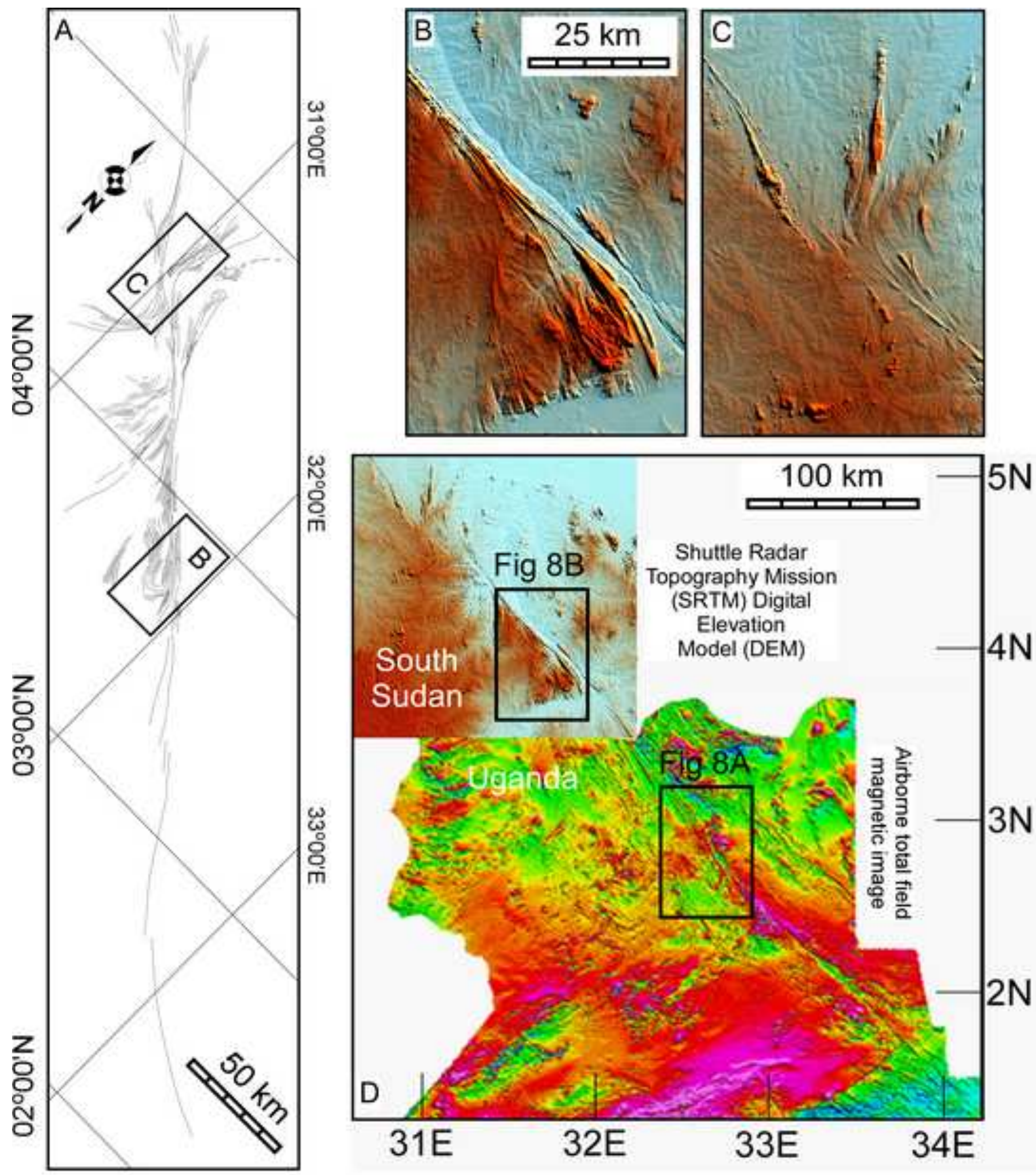

Figure 6 


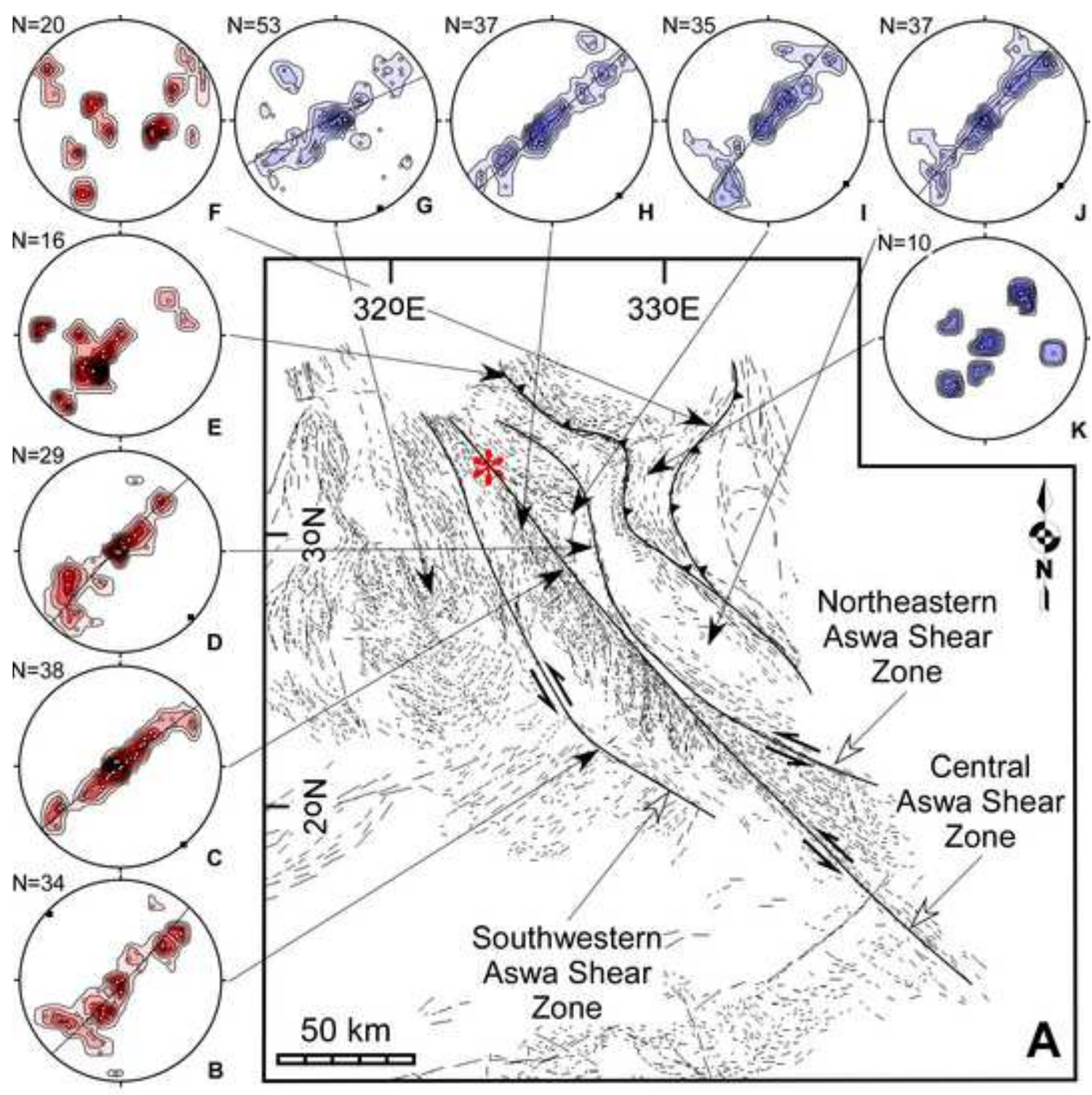

Figure 9 


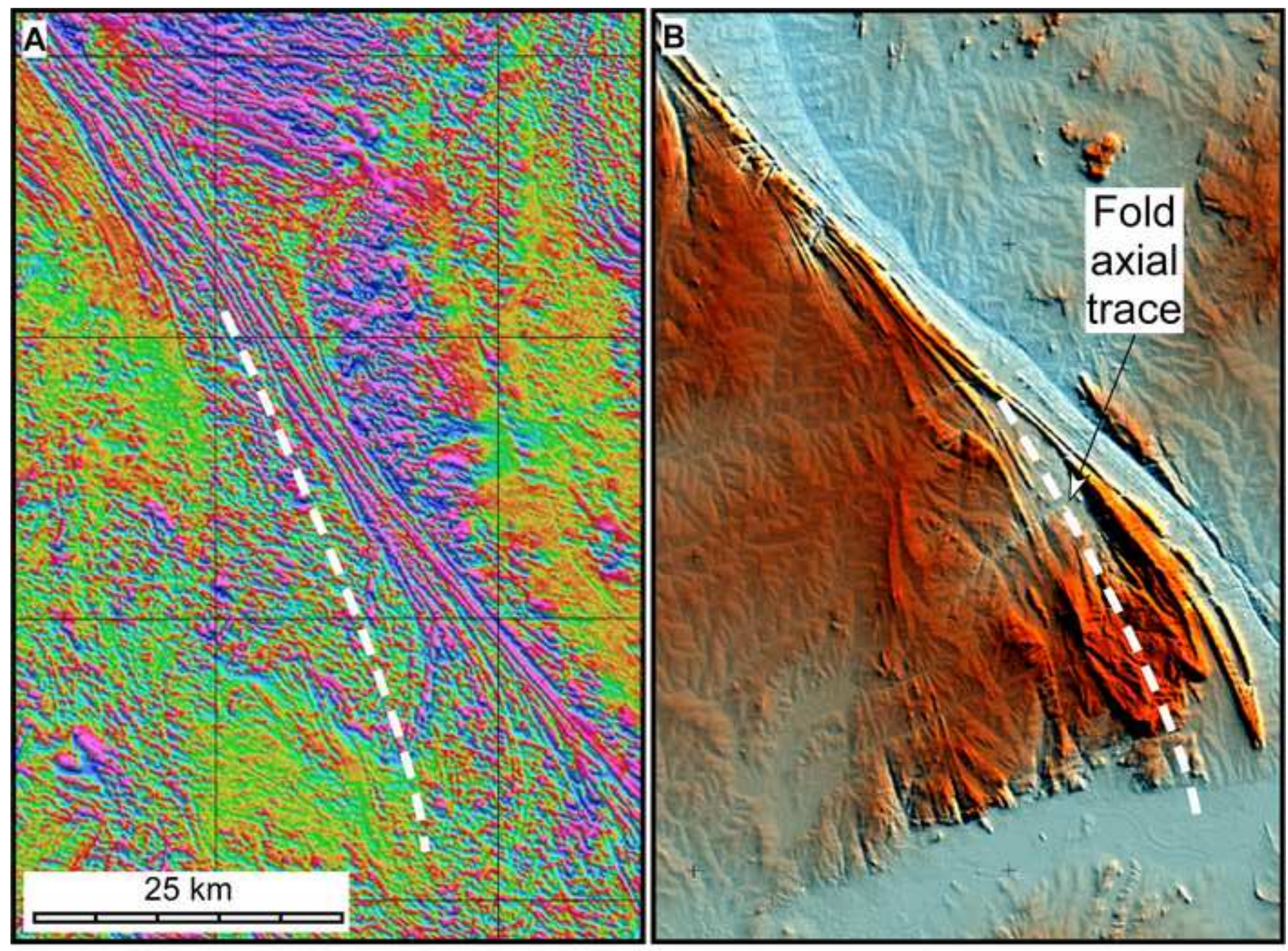

Figure 11 

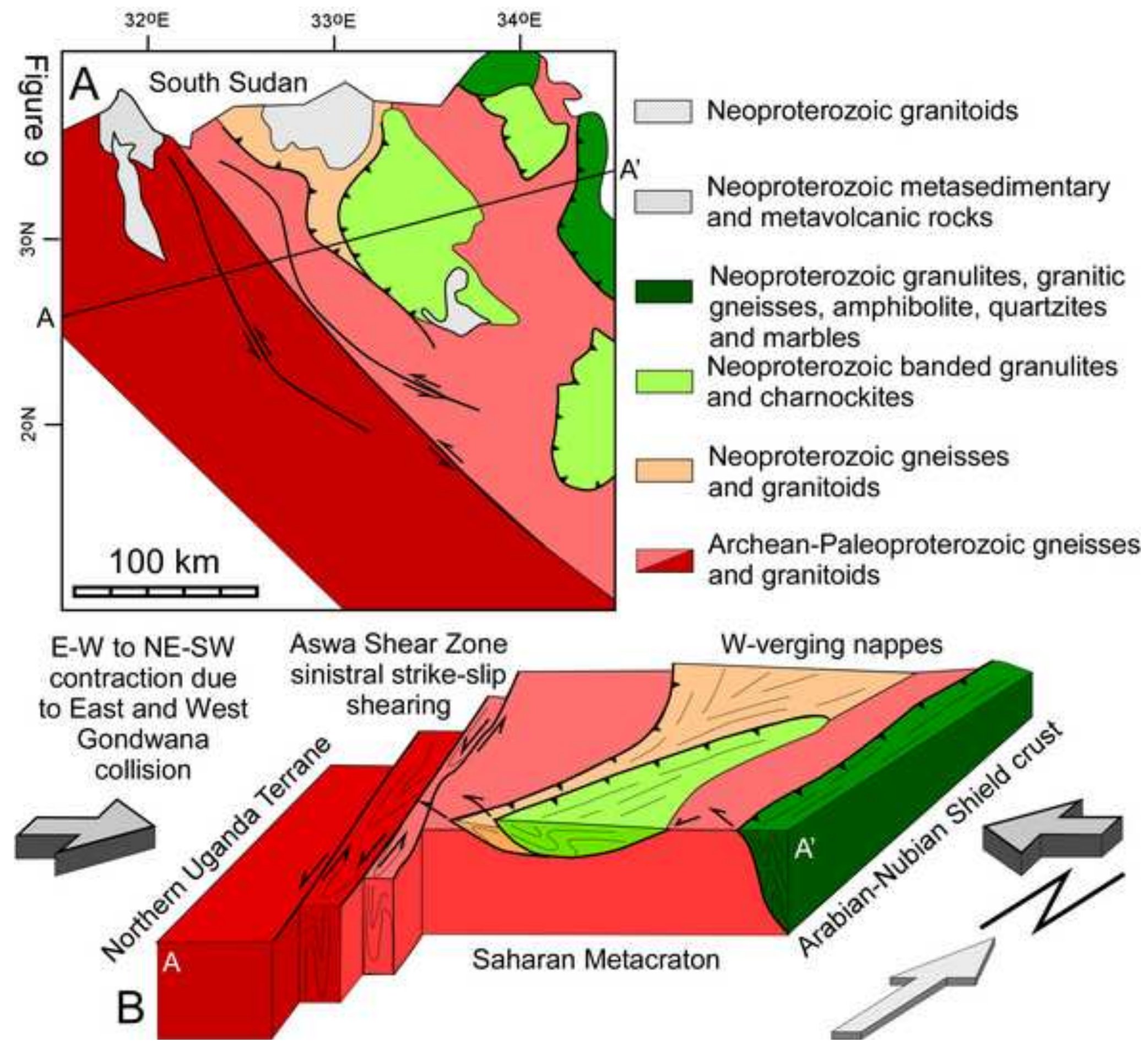